\title{
Generation and Analysis of Clonal IgM- and IgG-producing Human B Cell Lines Expressing an Anti-DNA-associated Idiotype
}

Audrey J. Manheimer-Lory, Anne Davidson, Dorothy Watkins, Noreen R. Hannigan, and Betty A. Diamond

Department of Microbiology and Immunology, Albert Einstein College of Medicine, Bronx, New York 10461

\begin{abstract}
This study describes a methodology for generating stable, cloned, EBV-transformed IgG- and IgM-producing human B cell lines. Using these lines we have characterized immunoglobulin $\mathrm{V}$ gene utilization in an anti-DNA-associated idiotypic system. The 31 anti-DNA-associated idiotype is encoded preferentially by the $V_{x} 1$ gene family, and, in all probability, reflects a germ line gene-encoded framework determinant. Analysis of these lines indicates that the DNA-binding antibodies produced by $B$ cell lines from SLE patients may differ from DNA binding myeloma proteins and from natural autoantibodies. (J. Clin. Invest. 1991. 87:1519-1525.) Key words: clonal EBV lines • anti-DNA idiotype • systemic lupus erythematosus - autoantibody
\end{abstract}

\section{Introduction}

Little is known about the etiology of autoantibody production in systemic lupus erythematosus (SLE), ${ }^{1}$ and animal models of the disease have led to disparate views. Many of the manipulations performed in studies of lupus-prone mice clearly cannot be undertaken in studies of the human disease; nonetheless, the study of the autoantibodies themselves can be very revealing. Serologic studies of SLE have employed idiotypic analyses to identify and characterize subsets of autoantibodies that bind DNA and structurally related antibodies that do not bind DNA. One approach has been to generate antiidiotypic reagents to monoclonal anti-DNA antibodies. However, it is not clear how closely the selected monoclonal autoantibodies mirror the pathogenic anti-DNA antibodies in disease. The approach favored by our laboratory has been to generate antiidiotypes to the heterogenous anti-DNA antibodies present in the serum and kidneys of individuals with SLE. The 3I antiidiotype recognizes a determinant on kappa light chains of antiDNA antibodies (1). High titered expression of 3I-reactive antibodies is present in $~ 80 \%$ of SLE patients with anti-DNA activity. We studied expression of the $3 I$ idiotype in the serum of relatives of SLE patients, as well as on monoclonal immunoglobulins in the serum of individuals with monoclonal gammopathies $(1,2)$ to obtain structural and genetic information

Address correspondence to Dr. Betty Diamond, Dept. of Microbiology and Immunology, Albert Einstein College of Medicine, 1300 Morris Park Ave., Bronx, NY 10461.

Received for publication 20 June 1990 and in revised form 17 October 1990.

1. Abbreviations used in this paper: dsDNA, double-stranded DNA; SLE, systemic lupus erythematosus.

J. Clin. Invest.

(c) The American Society for Clinical Investigation, Inc.

0021-9738/91/05/1519/07 \$2.00

Volume 87, May 1991, 1519-1525 about 3I-reactive antibodies. These analyses suggested two provocative hypotheses: $(a)$ autoantibodies and protective antibodies are structurally and probably genetically related; and $(b)$ malignant B cells express an immunoglobulin repertoire skewed towards autoreactivity. The study of myeloma proteins also suggested that the $3 I$ idiotype represents a germ line-encoded determinant on kappa light chains because $3 \mathrm{I}$ reactivity is common to both IgM and IgG antibodies. In contrast, a second antiidiotype, F4, recognizes a determinant on the heavy chain variable region of anti-DNA antibodies in $\sim 60 \%$ of patients with SLE with anti-DNA activity. ELISA and Western blot analyses of SLE sera and of myeloma proteins show F4 reactivity to be almost exclusively limited to cationic IgG antibodies and to be highly associated with DNA binding activity (3). Because F4 reactivity is present much more commonly on IgG than on IgM antibodies, the F4 antiidiotype may recognize a somatically generated determinant, the appearance of which is coincident with heavy chain class switching.

Although many studies of autoantibodies have focused on myeloma proteins, the monoclonal autoantibodies produced by malignant B cells may differ from the autoantibodies of autoimmune diseases. For this reason, it is crucial to pursue the analysis of pathogenic autoantibodies produced by B cells from autoimmune individuals. We now report the production of monoclonal EBV-transformed B cell lines from three individuals with SLE as well as from one with multiple myeloma whose myeloma protein expresses both the $3 \mathrm{I}$ and F4 idiotypes. We have generated IgM-, G-, and A-producing cell lines expressing the $3 \mathrm{I}$ idiotype and IgG-producing cell lines expressing the F4 idiotype. These cell lines were cloned; their immunoglobulin products were characterized to define antigenic specificity and RNA analyzed to determine variable region gene family utilization. We describe a protocol for generating cloned EBV-transformed lines and we demonstrate that SLE B cell lines differ from idiotypically related myeloma proteins; these differences may provide clues to the etiology of SLE.

\section{Methods}

Production and cloning of EBV-transformed cell lines. All SLE patients met revised ARA criteria for disease. Peripheral blood lymphocytes were obtained from two individuals with SLE. Blood was drawn at a time when the serum displayed elevated titers of idiotype reactive antibodies as tested by radioimmunoassay. Spleen cells were harvested from another individual with SLE who underwent splenectomy. Bone marrow was obtained from one patient with multiple myeloma whose myeloma protein is 3I- and F4-reactive. Mononuclear cells were isolated by centrifugation on Ficoll-Hypaque (Pharmacia Fine Chemicals, Piscataway, NJ), and plated at $1 \times 10^{6}$ cells/ml in 24-well tissue culture plates in RPMI (Gibco, Grand Island, NY) supplemented with $10 \%$ FCS (Hyclone Laboratories, Inc., Logan, UT), 1\% penicillin/streptomycin, $1 \%$ glutamine, $1 \%$ sodium pyruvate (Hazelton Biologics, Lenexa, KS), $1 \%$ nonessential amino acids (Gibco), and $0.01 \mathrm{mM}$ Hepes (Sigma Chemical Co., St. Louis, MO). To each well, $200 \mu l$ of supernatant from a dense culture of the EBV-infected Marmoset cell line (B95- 
8) (American Type Culture Collection, Rockville, MD), and $50 \mathrm{ng}$ of cyclosporine A was added. Transformants grew in every well. Each well was tested for idiotypic reactivity, i.e., for the presence of 3I- or F4-reactive immunoglobulin by ELISA. Antibodies were shown to be devoid of rheumatoid factor activity based on their inability to react with an isotype- and allotype-matched irrelevant IgG 1 antibody in the ELISA assay (data not shown). Cloning of cells was performed within $4 \mathrm{wk}$ of transformation. Cells were plated at $3,10,30$, and 100 cells/well in 96-well round-bottomed microtiter wells in medium supplemented with $10 \%$ FCS and $20 \% \mathrm{~J} 774$ conditioned medium. The mouse macrophage line $\mathbf{J 7 7 4}$ derives from a reticulum cell sarcoma and has been shown to produce a variety of macrophage specific factors $(4,5)$. The line was grown in DME medium with $10 \%$ FCS. Supernatant from a 48-h dense culture was harvested and filtered before use. Plates in which cells grew in more than one of every three wells were discarded. Presumed clones were grown to mass culture in RPMI medium supplemented as above but without the addition of $\mathrm{J} 774$ cell conditioned medium. For isotype, idiotype, and DNA binding assays described below, cells were grown in serum free medium.

Assay for isotype. The isotype of secreted immunoglobulin was determined by ELISA. Goat anti-human immunoglobulin $M, G$, and A (Sigma Chemical Co., St. Louis, MO) was adsorbed to microtiter wells (Costar 35, Cambridge, MA) at $10 \mu \mathrm{g} / \mathrm{ml}$. Wells were blocked with PBS $/ 3 \%$ BSA $/ 5 \%$ FCS. Supernatant $(100 \mu \mathrm{l} /$ well $)$ was added for $60 \mathrm{~min}$ at $37^{\circ} \mathrm{C}$. Wells were washed with PBS- $0.05 \%$ Tween and then incubated separately with peroxidase labeled goat anti-human IgM, IgG, or IgA (Sigma Chemical Co.). ABTS substrate (Kirkegaard and Perry Laboratories, Inc., Gaithersburg, MD) was added. ELISA plates were read at $\mathrm{OD}_{405}$.

Assays for idiotypic specificity. Because human cell lines may secrete varying amounts of immunoglobulin, secreted immunoglobulin from each cloned line was quantitated by ELISA. Goat anti-human immunoglobulin was adsorbed to microtiter wells at $1 \mu \mathrm{g} /$ well. Wells were blocked with PBS/3\% BSA/5\% FCS. Supernatant (100 $\mu \mathrm{l} /$ well) was added for $60 \mathrm{~min}$ at $37^{\circ} \mathrm{C}$. Wells were washed with PBS- $-0.05 \%$ Tween, and then incubated for $60 \mathrm{~min}$ with either peroxidase linked goat anti-human IgM or peroxidase-linked goat anti-human IgG (Sigma Chemical Co.). ABTS substrate was added. A standard curve was generated with purified IgM and IgG from a normal individual diluted in medium ranging from 0.5 to $50 \mu \mathrm{g} / \mathrm{ml}$.

Supernatants normalized for immunoglobulin concentration $(5 \mu \mathrm{g} /$ $\mathrm{ml}$ ) by dilution in medium were assayed for idiotypic reactivity. 3I or F4 antiidiotype, which was purified from ascitic fluid, was adsorbed to microtiter wells at 1 or $2 \mu \mathrm{g} /$ well, respectively. Wells were blocked with PBS/3\% BSA/5\% FCS as above and incubated with normalized cell supernatant for $1 \mathrm{~h}$ followed by peroxidase labeled goat anti-human IgG, IgM, or IgA (Cappel Laboratories, Cooper Biomedical, Malvern, $\mathrm{PA}$ ) for $1 \mathrm{~h}$ at $1 / 750$ dilution in PBS/1\% BSA, followed by incubation with ABTS substrate.

Assay for DNA reactivity. Anti-double-stranded DNA (dsDNA) activity was determined by filter assay (Millipore/Continental Water Systems, Bedford, MA). DNA was made double-stranded by filtration through nitrocellulose filters. $40 \mu \mathrm{l}$ of a supernatant containing either 5 and/or $1 \mu \mathrm{g} / \mathrm{ml}$ of antibody was incubated with 10,000 counts of ${ }^{32} \mathrm{P}$ nick-translated dsDNA for $30 \mathrm{~min}$ at $37^{\circ} \mathrm{C}$. Samples were then applied to prewet 1" Millipore filter discs (HA $0.45 \mu \mathrm{m}$ ) and washed through several times under vacuum. Discs were placed in scintillant and counted.

Southern blot analysis for assaying clonality. Cell lines were assayed for clonality by Southern blot analysis using specific human $J_{K}$ and $J_{H}$ probes (Table I). High molecular weight DNAs from the EBV lines were prepared essentially as described by Steffen et al. (6). Briefly, $10^{7}$ cells were suspended in $5 \mathrm{ml}$ of $100 \mathrm{mM} \mathrm{NaCl} 10 \mathrm{mM}$ Tris-HCl (pH 7.5 ) and $1 \mathrm{mM}$ EDTA. The suspension was then mixed with an equal volume of the same buffer containing $1 \%$ SDS and $400 \mu \mathrm{g} / \mathrm{ml}$ proteinase $\mathrm{K}$ (Boehringer Mannheim, GmbH, Mannheim, FRG) and incubated for $2 \mathrm{~h}$ at $37^{\circ} \mathrm{C}$. After incubation, 2 phenol and 2 SEVAG $(24: 1$ chloroform/isoamyl alcohol) extractions, DNA was precipitated with
Table I. Probes Utilized in Southern and Northern Analyses

\begin{tabular}{|c|c|c|}
\hline Probe & Characterization & Source \\
\hline $\mathbf{J}_{\mathbf{K}}$ & $\begin{array}{l}1.8 \mathrm{~kb} \text { Sac I fragment } \\
\text { inclusive } J_{K^{1}}-5\end{array}$ & Leder, P., Harvard University \\
\hline $\mathbf{J}_{\mathbf{H}}$ & $\begin{array}{l}1.0 \mathrm{~kb} \text { Bst EII fragment } \\
\text { most } 3^{\prime} \text { fragment }\end{array}$ & $\begin{array}{l}\text { Berman, J., F. Alt, Columbia } \\
\text { University }\end{array}$ \\
\hline $\mathrm{V}_{\mathrm{K}} 1$ & $\begin{array}{l}0.4 \mathrm{~kb} \text { Sac I-Pst I } \\
\text { fragment }\end{array}$ & $\begin{array}{l}\text { Zachau, H., University of } \\
\text { Munich }\end{array}$ \\
\hline $\mathrm{V}_{\mathrm{K}} 2$ & $\begin{array}{l}0.4 \mathrm{~kb} \text { Hind III-Eco RI } \\
\text { fragment }\end{array}$ & $\begin{array}{l}\text { Zachau, H., University of } \\
\text { Munich }\end{array}$ \\
\hline $\mathrm{V}_{\mathrm{K}} \mathbf{3}$ & $\begin{array}{l}0.4 \mathrm{~kb} \text { Hind III-Eco RI } \\
\text { fragment }\end{array}$ & $\begin{array}{l}\text { Zachau, H., University of } \\
\text { Munich }\end{array}$ \\
\hline $\mathrm{V}_{\mathrm{K}} 4$ & $\begin{array}{l}0.4 \mathrm{~kb} \text { Hind III-Eco RI } \\
\text { fragment }\end{array}$ & $\begin{array}{l}\text { Zachau, H., University of } \\
\text { Munich }\end{array}$ \\
\hline $\mathrm{V}_{\mathrm{H}} 1$ & $\begin{array}{l}0.4 \mathrm{~kb} \text { Eco RI-Bst EII } \\
\text { fragment }\end{array}$ & $\begin{array}{l}\text { Berman, J., F. Alt, Columbia } \\
\text { University }\end{array}$ \\
\hline $\mathrm{V}_{\mathrm{H}^{2}} 2$ & $\begin{array}{l}0.38 \mathrm{~kb} \text { Sal I-Eco RI } \\
\text { fragment }\end{array}$ & $\begin{array}{l}\text { Berman, J., F. Alt, Columbia } \\
\text { University }\end{array}$ \\
\hline$V_{H} 3$ & $\begin{array}{l}0.5 \mathrm{~kb} \text { Nco I-Bst IEII } \\
\text { fragment }\end{array}$ & $\begin{array}{l}\text { Berman, J., F. Alt, Columbia } \\
\text { University }\end{array}$ \\
\hline $\mathrm{V}_{\mathrm{H}} 4$ & $\begin{array}{l}0.47 \mathrm{~kb} \text { Bam-Eco RI } \\
\text { fragment }\end{array}$ & $\begin{array}{l}\text { Berman, J., F. Alt, Columbia } \\
\text { University }\end{array}$ \\
\hline$V_{H} 5$ & $\begin{array}{l}0.38 \mathrm{~kb} \text { Hinc II-Pst I } \\
\text { fragment }\end{array}$ & $\begin{array}{l}\text { Berman, J., F. Alt, Columbia } \\
\text { University }\end{array}$ \\
\hline $\mathrm{V}_{\mathrm{H}} 6$ & $\begin{array}{l}0.30 \mathrm{~kb} \text { Eco RI-Stu I } \\
\text { fragment }\end{array}$ & $\begin{array}{l}\text { Berman, J., F. Alt, Columbia } \\
\text { University }\end{array}$ \\
\hline
\end{tabular}

2.5 vol ethanol and dissolved in a minimal volume $10 \mathrm{mM}$ Tris- $\mathrm{HCl}$ (pH 7.5) 1 mM EDTA. $10 \mu \mathrm{g}$ DNA was digested with Eco RI or Bam HI (New England Biolabs, Inc., Beverly, MA) and electrophoresed on $0.8 \%$ agarose gels. Subsequently, DNA was transferred to nitrocellulose filters and hybridized to a radiolabeled human $\mathbf{J}_{\mathbf{K}}$ probe (Leder, P., Harvard University, Cambridge, MA) or a human $J_{H}$ probe (Berman, J., and F. Alt, Columbia University, New York). Blots were washed at $68^{\circ} \mathrm{C}$ in $2 \times$ SSC, $0.1 \%$ SDS. Only cell lines which exhibited no more than two heavy chain or kappa light chain rearrangements were selected for further study.

Northern blot analysis of total RNA for $V$ gene utilization. Total RNA was prepared from $1 \times 10^{8}$ cells using the guanidinium thiocyanate extraction procedure (7). Briefly, frozen or fresh cells were added directly to $4 \mathrm{M}$ guanidinium thiocyanate solution and homogenized immediately using a polytron. This homogenate was carefully layered onto a $5.7 \mathrm{M} \mathrm{CsCl}$ cushion and tubes were spun in a SW41 rotor (Beckman Instruments, Inc., Fullerton, CA) at $32 \mathrm{~K}$ for $18 \mathrm{~h}$ at $20^{\circ} \mathrm{C}$. Supernatants were quickly suctioned off. RNA pellets were rinsed in $100 \%$ ethanol at $25^{\circ} \mathrm{C}$, resuspended in $10 \mathrm{mM}$ Tris $1 \mathrm{mM}$ EDTA (pretreated with DEPC), extracted once with Phenol-Sevag solution and precipitated twice with $1 / 10$ volume $4 \mathrm{M} \mathrm{NaCl}$ (DEPC) and 2 vol of ethanol. Northern blotting was performed by electrophoretically fractionating the RNA on a $1.2 \%$ agarose gel (6\% formaldehyde) in $40 \mathrm{mM}$ MOPS, 20 mM NaOAc, 2 mM EDTA. The gel was blotted without pretreatment onto nitrocellulose using $20 \times \mathrm{SSC}(3 \mathrm{M} \mathrm{NaCl} 0.3 \mathrm{M}$ Na-citrate).

Variable region gene families of both heavy and light chains were assigned based upon hybridization of total RNA to each of six probes representing all identified $V_{H}$ gene families and to each of four probes representing all identified $V_{K}$ gene families (Table I). Plasmids for each $\mathrm{V}_{\mathrm{H}}$ probe were kindly provided by Jeffrey Berman and Fred Alt of Columbia University. Plasmids containing the $\mathrm{K}$ light chain family specific probes were provided by Hans Zachau (University of Munich, FRG). V region specific probes were prepared to insure minimal crosshybridization. 
Blots were hybridized using nick-translated probes in $50 \%$ formamide (EM Science, Cherry Hill, $\mathrm{NJ}$ ) at $42^{\circ} \mathrm{C}$ overnight. Subsequently, blots were washed in $2 \times \mathrm{SSC}, 0.1 \% \mathrm{SDS}$ at $68^{\circ} \mathrm{C}$ and autoradiographed.

Sequencing the heavy chain rearrangement of $\mathrm{H}_{2} F .10 \mu \mathrm{g}$ total RNA was used to reverse transcribe into first-strand CDNA using a specific $\mathrm{C} \gamma$ primer 5'GCCAGGGGGAAGACCGATGG3'. The reaction was carried out in a 50- $\mu$ l reaction mixture according to the standard protocol provided by Amersham Corp. (Arlington Heights, IL). Secondstrand synthesis was carried out by the polymerase chain reaction method. The reaction ( $100 \mu \mathrm{l}$ volume) contained $250 \mu \mathrm{m}$ of each dNTP, $1.5 \mathrm{mM} \mathrm{MgCl}_{2}, 50 \mathrm{mM} \mathrm{KCl}, 20 \mathrm{mM}$ Tris- $\mathrm{HCl}$ (pH 8.4 at room temperature), $2.5 \mathrm{U}$ of Taq polymerase (Perkin Elmer Corp., Norwalk, CT), $1 \mu \mathrm{g}$ of $\mathrm{C} \gamma$ primer and $1 \mu \mathrm{g}$ of a $5^{\prime} \mathrm{V}_{\mathrm{H}} 3$ specific 20-mer 5'AGGTGCAGCTGGTGGAGTCT3'. 30 reaction cycles were performed under the following conditions: denaturation $\left(94^{\circ} \mathrm{C}, 1 \mathrm{~min}\right)$, annealing $\left(48^{\circ} \mathrm{C}, 1 \mathrm{~min}\right)$ and extension $\left(72^{\circ} \mathrm{C}, 3 \mathrm{~min}\right)$. Elution of specific DNA product was done from a $2.5 \%$ low-melt agarose gel (NuSieve GTG; FMG Biproducts, Rockland, ME). The gel slice was heated for $5 \mathrm{~min}$ at $68^{\circ} \mathrm{C}$ and the volume was adjusted to $500 \mu \mathrm{l}$ with TE pH 8. $500 \mu \mathrm{l}$ of phenol was added and the aqueous layer was extracted. An equal volume of phenol:SEVAG (chloroform:isoamyl alcohol, 24:1) was then added and the aqueous layer was extracted. One ether extraction was done and then the DNA was ethanol precipitated (1/10 vol sodium acetate +2 vol $100 \%$ ethanol). DNA was sequenced using ${ }^{35}$ S-alpha thio ATP and the dideoxy termination method of sequenase with the addition of $10 \%$ DMSO to all reactants.

\section{Results}

EBV-transformed cell lines were produced from three individuals with SLE and one individual with multiple myeloma. All three patients with SLE had elevated titers of both 3I- and F4-reactive antibodies in their serum on several occasions. The myeloma patient had a 3I- and F4-reactive DNA-binding myeloma protein. Cells were propagated in bulk cultures and, therefore, it was not possible to determine a transformation frequency. Each well of $10^{6}$ peripheral blood mononuclear cells grew multiple transformants, demonstrating a frequency $>1$ in $10^{6}$ cells.

Supernatants from cultures of transformed cells were analyzed for the presence of immunoglobulin expressing the 3I and F4 idiotypes. Supernatants were considered positive for idiotype if the mean of the duplicates were greater than four standard deviations above the mean of the negative control. Cells from 3I-reactive or 3I- and/or F4-reactive wells were cloned by limiting dilution. In every case, it was possible to clone 3I-reactive lines from 3I-reactive polyclonal cultures and 3I- and F4-reactive lines from 3I- and F4-reactive cultures, even though it is, in general, difficult to clone EBV-transformed B cell lines. Attempting to optimize conditions for cloning these B cell lines, we assayed different conditioned media for increased cloning efficiency. Whereas supernatants from concanavalin A-stimulated peripheral blood mononuclear cells and the U937 human monocytelike line showed no appreciable effect, we found that medium from the murine macrophagelike line $\mathrm{J} 774$ was able to greatly enhance the cloning efficiency. Using this medium, we can routinely plate cells at a concentration of 3-30 cells/well in $100 \mu \mathrm{l}$ of medium. Cells grow to mass culture in approximately one-fourth to one-third of all wells suggesting a cloning efficiency of $1-10 \%$. After a single round of limiting dilution cloning, cells were reassayed for idiotype expression. Those lines that were 3I positive were shown to express a single heavy chain constant region and a single light chain constant region suggesting clonality.
We confirmed the clonality of lines by analyzing Southern blots of DNA digested with two enzymes and probed with a $\mathbf{J}_{\mathbf{H}}$ and a $J_{K}$ probe. Most lines contained two rearranged heavy chain loci and two rearranged light chain loci. Some clones, however, did show one germ line fragment and only a single gene rearrangement of either the heavy chain or light chain locus. Genomic Southerns from several EBV-transformed lines blotted with $J_{K}$ and $J_{H}$ probes are illustrated in Fig. 1. One line, IC4, is derived from the patient with multiple myeloma, although it does not represent the myeloma protein; the other three lines shown in Fig. 1 come from a single patient with SLE. Each displays different $J_{H}$ and $J_{K}$ gene rearrangements showing them to be different lines. We report here clones that clearly differ from each other by DNA rearrangement. Whereas this means that some clones which differ from each other by somatic mutation but not by a restriction fragment length polymorphism analysis would never be distinguished from each other, it does ensure that each clone represents an independent transformation event.

After cloning, 3I reactivity was reassayed on supernatants normalized for immunoglobulin concentrations. Results for idiotypic reactivity in supernatants from cloned lines are shown in Table II. All lines express the 3I idiotype. Three of the lines also express the F4 idiotype. All three of these produce an IgG antibody (see below). The cell lines display a spectrum of idiotypic reactivity.

Isotype and variable region gene usage by EBV lines. Antibodies secreted by unselected EBV-transformed cells have been consistently reported to be of the IgM isotype. In contrast, we found a substantial percentage of idiotype positive clones producing IgG antibodies. Whereas $50 \%$ of the lines reported here are IgG producing, 10-20\% of all the 3 I idiotypic positive lines obtained were IgG. All F4-positive antibodies were IgG.
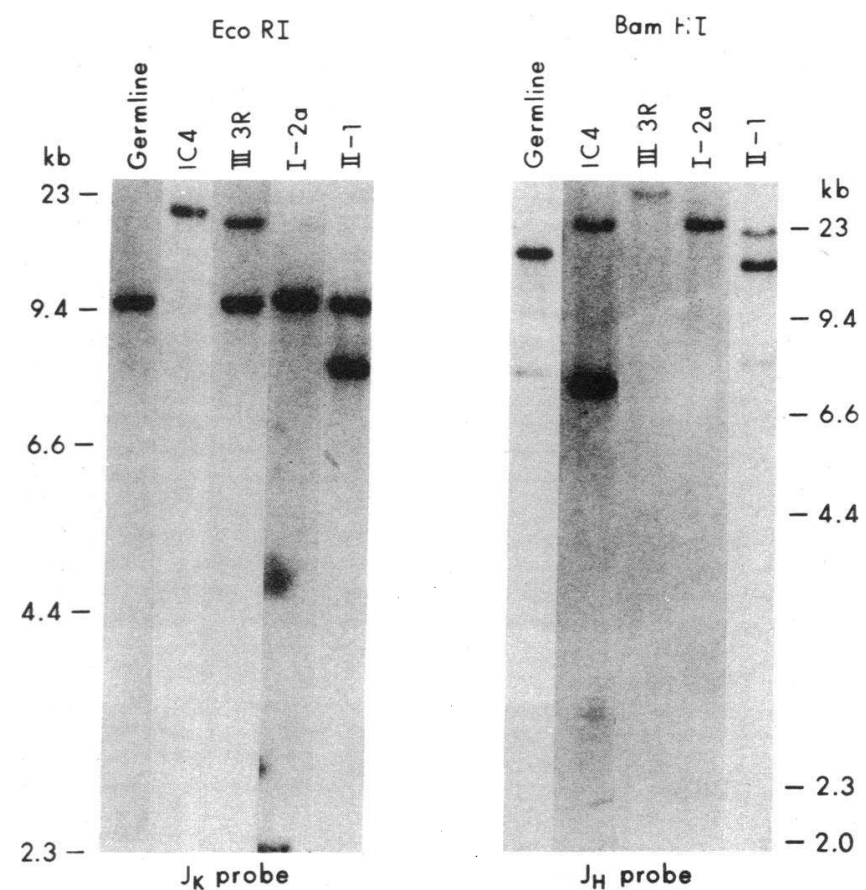

Figure 1. Southern analysis of human germ line DNA and heavy and light chain rearrangements of EBV cell line DNA digested with Eco $\mathrm{RI}$ and Bam $\mathrm{HI}$ and probed with ${ }^{32} P$ nick-translated $\mathrm{J}_{\mathrm{K}}$ and $\mathrm{J}_{\mathrm{H}}$ probes. Germline $J_{K}$ is $9.4 \mathrm{~kb}$ and germ line $J_{H}$ is $17 \mathrm{~kb}$. 


\begin{tabular}{|c|c|c|c|c|c|}
\hline \multirow{2}{*}{$\begin{array}{l}\text { Cell } \\
\text { line }\end{array}$} & \multirow{2}{*}{$\begin{array}{c}\text { Patient } \\
\text { origin }\end{array}$} & \multirow[b]{2}{*}{ Tissue } & \multirow[b]{2}{*}{ Isotype } & \multicolumn{2}{|c|}{ OD $405 \pm 2$ SD } \\
\hline & & & & $3 I$ & F4 \\
\hline IC4 & HIC (myeloma) & Bone marrow & IgM & $409 \pm 15.5$ & $215 \pm 3.0$ \\
\hline $2 \mathrm{~A} 4$ & HIC (myeloma) & Bone marrow & IgG & $931 \pm 7.0$ & $745 \pm 11.5^{*}$ \\
\hline III-3R & DIL (SLE) & Spleen & IgM & $741 \pm 7.8$ & $154 \pm 1.4$ \\
\hline III-2R & DIL (SLE) & Spleen & IgM & $859 \pm 40.0$ & $261 \pm 5.5$ \\
\hline II-1 & DIL (SLE) & Spleen & IgM & $542 \pm 0$ & $248 \pm 28.0$ \\
\hline $\mathrm{I}-2 \mathrm{a}$ & DIL (SLE) & Spleen & IgG & $1012 \pm 26.0$ & $449 \pm 37.5^{*}$ \\
\hline IX7RG1 & DIL (SLE) & Spleen & IgA & $517 \pm 10.6$ & $112 \pm 4.2$ \\
\hline HF2 & HER (SLE) & PBL & IgM & $555 \pm 23.0$ & $306 \pm 10.8$ \\
\hline $\mathrm{H} 2 \mathrm{~F}$ & HER (SLE) & PBL & IgG & $912 \pm 45.0$ & $1082 \pm 27.5^{*}$ \\
\hline R3.5H.5G & RIO (SLE) & PBL & IgG & $892 \pm 86.5$ & $288 \pm 7.5$ \\
\hline
\end{tabular}

Purified protein $(5 \mu \mathrm{g} / \mathrm{ml})$ from a EBV-transformed non-3I (158 \pm 23$)$, nonreactive F4 line (318 \pm 13$)$ was utilized as negative controls. All lines are 3I positive. * F4-positive lines.

Similar figures were obtained whether peripheral blood cells, spleen cells, or bone marrow cells were transformed.

Northern blotting was utilized to determine which heavy and light chain variable region gene families were represented in our panel of antibodies. 5-7 $\mu \mathrm{g}$ of total RNA was blotted on nitrocellulose and probed with $\mathrm{V}$ specific probes representing all reported human $V_{K}$ gene families (Fig. 2). Analysis of the $V_{K}$ families utilized indicates that $3 \mathrm{I}$ reactive lines preferentially use a member(s) of the $V_{K 1}$ family; all but 2 of 10 3I-reactive antibodies are encoded by a $V_{K} 1$ gene (Table III). No clone expresses more than one $V_{K}$ family. Whereas two lines were derived from the patient with myeloma, neither line is producing the myeloma protein. Both lines produce a $V_{K} 1$-encoded light chain, whereas the myeloma protein is a $V_{K} 3$ encoded light chain (8).

It is apparent that no single $V_{H}$ region family is used by the 3I-positive antibodies (Fig. 3). Four of the six currently defined
$\mathrm{V}_{\mathrm{H}}$ families are expressed in these 3I-reactive lines. Even when clones from the same individual are examined, more than one $\mathrm{V}_{\mathrm{H}}$ family is expressed in $3 \mathrm{I}$-reactive antibodies and in the DNA binding subset of 3I-reactive antibodies. For example, III-3R, III-2R, and II-1 are all derived from a single patient; they express a $V_{H} 3, V_{H} 5$, and $V_{H} 1$ gene product, respectively. Whereas only three F4-reactive lines were studied, there is no evidence suggesting that a single $V_{H}$ gene family associates with $\mathrm{F} 4$ reactivity. Of the three $\mathrm{F} 4$-positive lines, one uses a member of the $V_{H^{4}}$ family and two use a member of the $V_{H} 3$ family. Both these gene families are also used in the same patients to encode antibodies that lack F4 reactivity. To see if F4 idiotypic specificity resides in the third complementarity-determining region, we sequenced the $D$ region of the heavy chain from the H2F antibody and compared it to the D sequence of the 2A4 antibody (Fig. 4). The sequences in the $D$ region are sufficiently divergent to suggest that $\mathrm{F} 4$ reactivity does not reside in CDR3.

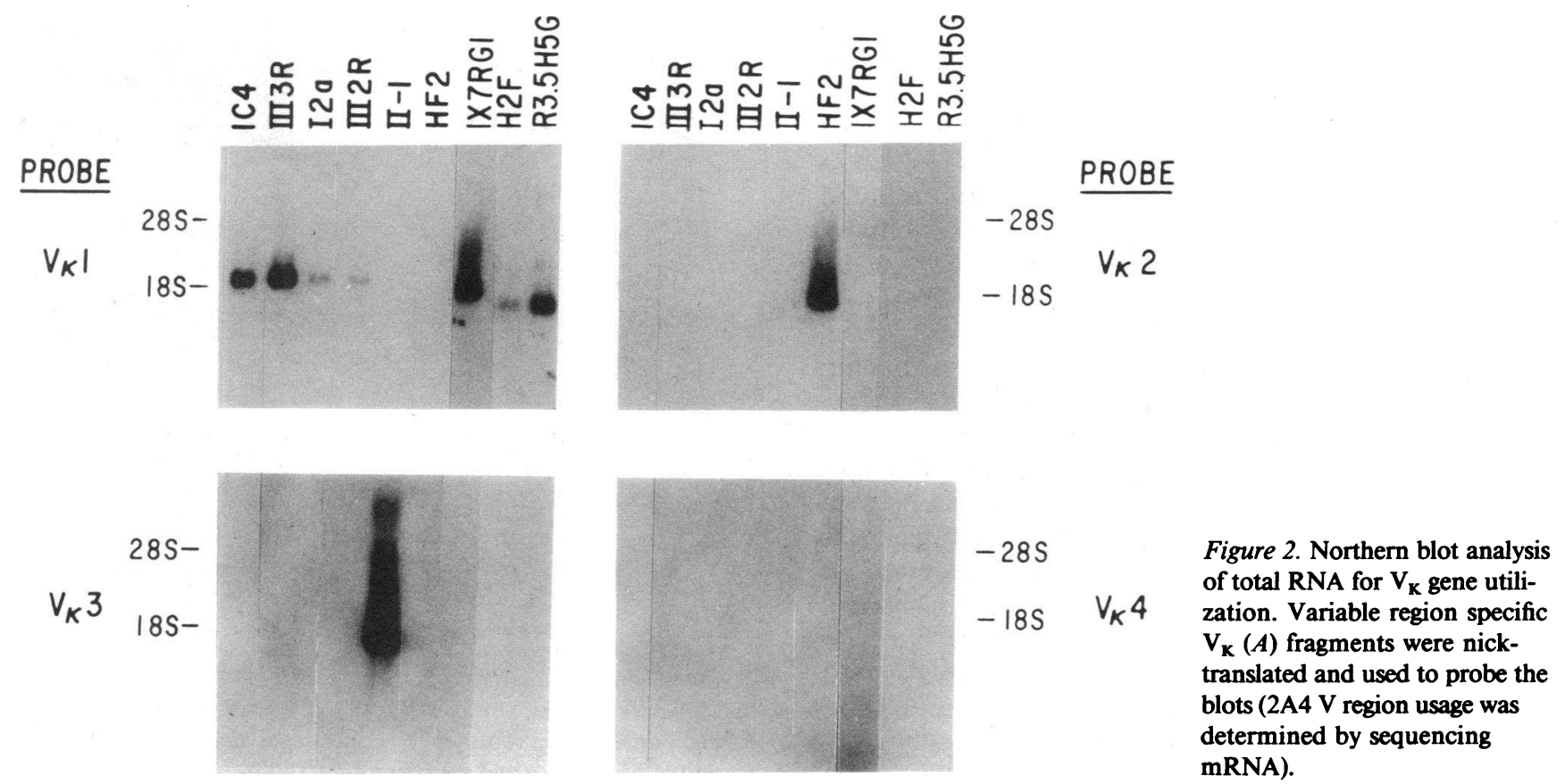


Table III. Variable Region Gene Usage

\begin{tabular}{llll}
\hline & & \multicolumn{2}{c}{ Gene family } \\
\cline { 3 - 4 } Patient & \multicolumn{1}{c}{ Cell line } & $\mathrm{V}_{\mathbf{k}}$ & $\mathrm{V}_{\mathbf{H}}$ \\
\hline \multirow{2}{*}{ HIC } & IC4 IgM & 1 & 4 \\
& 2A4* IgG & 1 & $4^{*}$ \\
DIL & III-3R IgM & 1 & 3 \\
& III-2R IgM & 1 & 1 \\
& II-1 IgM & 3 & 5 \\
& I-2a* IgG & 1 & $3^{*}$ \\
HER & IX7RG1 IgA & 1 & 3 \\
& HF2 IgM & 2 & 3 \\
RIO & H2F* IgG & 1 & $3^{*}$ \\
& R3.5H.5G IgG & 1 & 1
\end{tabular}

Summary table of $\mathrm{V}_{\mathrm{L}}$ and $\mathrm{V}_{\mathrm{H}}$ genes utilized by EBV-transformed cell lines as determined by Northern blot. ${ }^{*} \mathrm{~F}_{4}$ positive lines.

Antigenic specificity. Double-stranded DNA binding was demonstrated by Millipore filter assay. The Millipore filter assay is a clinical assay which is used to demonstrate high-affinity anti-DNA reactivity. In fact, when only $40 \mathrm{ng}$ of antibody was used in the assay all the lines except R3.5H5G exhibited some anti-DNA activity as DNA binding was greater than four standard deviations above the mean of three normal control IgG fractions. The lines varied enormously in their relative affinities for dsDNA (Table IV). Previous studies of myeloma proteins had shown that in the 3 I idiotype system IgG antibodies are more likely to bind DNA than IgM antibodies. The five IgM antibodies we studied, four from SLE patients and one from a myeloma patient, all bind DNA, suggesting that the *
Figure 4. Derived amino acid sequence of the $D$ region of $\mathrm{H} 2 \mathrm{~F}$ compared to

IgM antibodies of SLE patients may differ from the IgM antibodies in nonautoimmune individuals.

\section{Discussion}

The advent of hybridoma technology made it possible to generate murine monoclonal antibodies essentially at will. Human hybridoma technology has not been so successful $(9,10)$. Fusion frequencies are generally low, stability is poor, and the amount of secreted immunoglobulin is very small. EpsteinBarr virus has also been used to transform human B cells, but EBV-transformed B cells have also been somewhat unstable, when lines are grown as uncloned populations (11). Previously, others have reported the generation of only IgM producing B cells (12-14). Nakamura et al. generated cloned, IgG-producing lines but only when human peripheral blood mononuclear cells were used as feeder cells (15). These cloned lymphocytes were stable for only a number of months. In addition, the presence of such feeder cells precludes studies of cell line RNA and DNA. To study the molecular genetics of anti-DNA antibodies from patients with SLE, it is necessary to be able to maintain stable cloned IgM- and IgG-producing B cell lines in the absence of any other cells. Therefore, we had to first devise a protocol for generating such lines. In this study the use of conditioned medium in conjunction with a single round of early cloning by limiting dilution permitted the establishment of long term, stable, clonal EBV-transformed lines. These lines have been growing for over a year and they secrete between 0.5

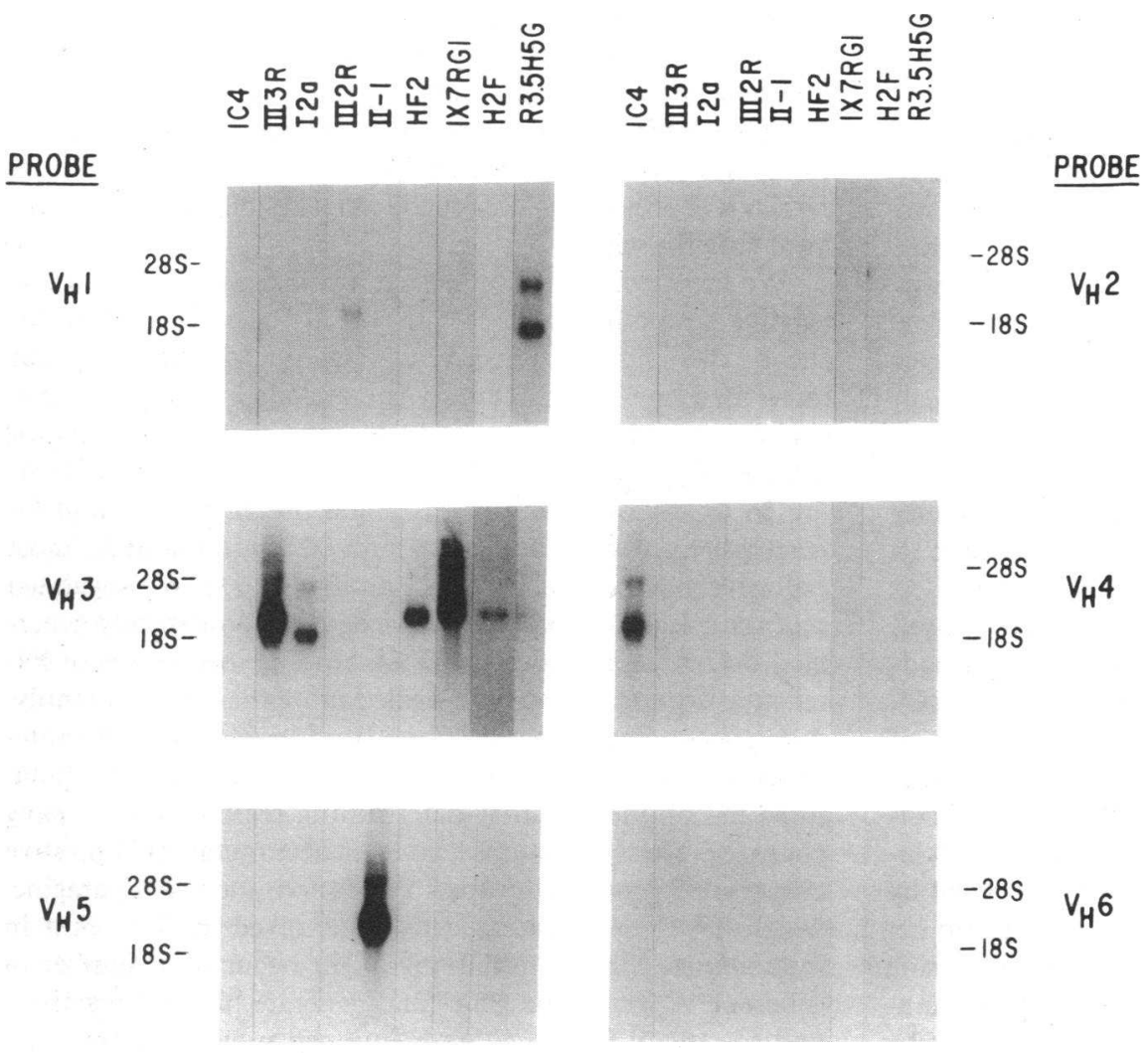

Figure 3. Northern blot analysis of total RNA for $V_{H}$ gene utilization performed as described for $V_{K}$ gene utilization. 
Table IV. Millipore Filter Binding Assay for dsDNA Reactivity

\begin{tabular}{lc}
\hline IC4 & $2187 \pm 857^{*}$ \\
& $995 \pm 76^{\ddagger}$ \\
$2 A^{8}$ & $5351 \pm 123^{*}$ \\
& $2404 \pm 1419^{\ddagger}$ \\
III-3R & $1326 \pm 375^{\ddagger}$ \\
III-2R & $1499 \pm 299^{*}$ \\
II-1 & $574 \pm 139^{\ddagger}$ \\
& $263 \pm 31^{*}$ \\
I-2as & $206 \pm 74^{\ddagger}$ \\
& $793 \pm 69^{*}$ \\
IX7RG1 & $159 \pm 11^{\ddagger}$ \\
HF2 & $334 \pm 228^{*}$ \\
& $198 \pm 28^{\ddagger}$ \\
H2F & $3080 \pm 431^{*}$ \\
& $541 \pm 27^{\ddagger}$ \\
R3.5H.5G & $1423 \pm 71^{*}$ \\
R & $126 \pm 42^{\ddagger}$ \\
J & $48 \pm 8^{*}$ \\
W & $59 \pm 2^{*}$ \\
& $36 \pm 2^{\ddagger}$ \\
& $55 \pm 20^{*}$ \\
& $60 \pm 32^{*}$ \\
\end{tabular}

$\mathrm{R}, \mathrm{J}$, and $\mathrm{W}$ represent purified immunoglobulin from normal individuals. Data are expressed as mean counts per minute $\pm 2 \mathrm{SD}$. Antibody concentrations are ${ }^{*} 5$ and ${ }^{\ddagger} 1 \mu \mathrm{g} / \mathrm{ml}$, respectively. ${ }^{8} \mathrm{~F} 4$ positive lines.

and $5 \mu \mathrm{g}$ of immunoglobulin per $10^{6}$ cells per $24 \mathrm{~h}$. We were successful in generating a large number of IgG-producing lines. Nakamura et al. report a higher frequency of IgG-producing clones in EBV-transformed cells from autoimmune individuals than from normal individuals (15). They found a frequency for wells containing IgG-producing B cells from patients with Hashimoto's disease and SLE of $\sim 10 \%$, similar to that which we report. Whereas this increased frequency may reflect a feature of the $B$ cells of autoimmune individuals, we were able to derive IgG-producing lines from the myeloma patient as well. It may be that early cloning permits the stabilization of IgG producing lines, or that IgG-producing lines can be more readily derived from bone marrow cells and spleen cells than peripheral blood cells. Because IgG-producing cell lines can be transformed and maintained in the absence of feeder cells, it will be possible to study the role of somatic mutation in the production of anti-self antibodies, and to directly analyze the IgG antibodies that are thought to contribute to pathogenesis.

Our second goal was to determine the $\mathrm{V}$ region genes used to encode an idiotypically defined subset of anti-DNA antibodies. An understanding of the genes used to produce anti-DNA antibodies and other autoantibodies will facilitate studies of immunoglobulin gene polymorphisms that might constitute part of a genetic predisposition to disease. Carson and colleagues have shown that rheumatoid factors, at least monoclonal rheumatoid factors, are encoded to a very great extent by $\mathrm{V}_{\mathbf{K}}$ III genes (16). This restriction may be somewhat biased because they have selected only rheumatoid factors expressing the Wa idiotype. Our study demonstrates that anti-DNA antibodies of the $3 I$ idiotype are encoded almost exclusively by genes of the $V_{K} 1$ gene family. This association is consistent with data we have obtained studying serum antibodies and myeloma proteins which suggested that the $3 I$ idiotype was a germ line gene-encoded framework determinant. The $V_{K} 1$ gene family is a large family and not all the members of this family have been cloned and sequenced. It is not yet clear whether all members of the $V_{K} 1$ family encode 3I-reactive antibodies and/or anti-DNA antibodies or whether only a subset of $V_{K} 1$ genes is used. The fact that two 3I-reactive antibodies are not encoded by $V_{K} 1$ genes shows that the 3I epitope is not restricted to the $V_{K} 1$ gene family. $V_{K} 1$-encoded antibodies are $\sim 70 \%$ homologous at the protein level to $V_{K}$ 2- and $V_{K}$ 3-encoded antibodies. It is quite possible, therefore, that certain epitopes be encoded by more than one gene family. It has been shown in a number of idiotype systems that more than one $\mathrm{V}$ region gene may encode a given idiotype. The CRI idiotype of anti-arsonate antibodies is encoded by a different gene family in $\mathrm{A} / \mathrm{J}$ mice than in BALB/c mice (17). The A48 idiotype expressed on anti-levan antibodies is present primarily on antibodies encoded by the $7183 \mathrm{~V}_{\mathrm{H}}$ family but also on an antibody encoded by a member of the J558 gene family (18). A wide variety of $V_{K}$ genes are used to encode antibodies bearing the A48 idiotype. Anti-DNA antibodies bearing the $\mathrm{H} 130$ idiotype can be encoded by a J558 $\mathrm{V}_{\mathrm{H}}$ gene or by a $7183 \mathrm{~V}_{\mathrm{H}}$ gene (19). Such studies demonstrate how difficult it can be to determine the structural basis for idiotype expression. Substantial sequence homology among the idiotypically related products of different $\mathrm{V}$ gene families may exist or, indeed, be of very limited homology $(17,20)$. Such regions of homology, however large or small, may well explain an idiotype encoded by more than one $V$ region gene family. Continued study of the available panel of $B$ cell lines should help answer these questions.

The fact that multiple $V_{H}$ gene families are associated with 3I-reactive anti-DNA antibodies might suggest that no single heavy chain family is critical in determining antigenic specificity of these antibodies. Recently, Logtenberg et al. reported a preferential usage of the $\mathrm{V}_{\mathrm{H}} 6$ gene in four IgM anti-ssDNA antibodies derived from healthy individuals (21). They have speculated that this restriction may be important in anti-DNA antibodies produced by SLE patients as well. We have, however, not obtained any $\mathrm{V}_{\mathrm{H}} 6$-encoded DNA-binding antibodies from patients with SLE.

We have not yet characterized a sufficient number of F4reactive antibodies to be certain which $V_{H}$ gene families can encode this idiotype. The limited data available showing that more then one $V_{H}$ gene family can encode $F 4$ reactive heavy chains is consistent with the hypothesis that $V_{H}$ framework residues may not be critical in generating anti-DNA antibodies. In a previous study of myeloma proteins, we found F4 reactivity to be highly associated with DNA binding and almost exclusively associated with IgG antibodies (3). We suggested that the F4 antiidiotype might recognize a somatically generated determinant critical to DNA binding. Sequences of F4reactive myeloma proteins revealed more than one $V_{H}$ family. A detailed molecular study of one 3I-positive, F4-positive antiDNA antibody, 2A4, revealed the acquisition of somatic mutations in complementarity-determining regions of the heavy chain (8). These mutations lead to an accumulation of positive charges and generate the amino acids arginine and asparagine, which have been postulated to be involved in DNA-protein interactions. Similar mutations might occur in a number of different $V_{H}$ germ line genes and generate both $F 4$ reactivity and specificity for DNA. As mentioned previously, there are 
studies which have shown that antibodies utilizing different $V_{\mathbf{H}}$ and $V_{K}$ genes can still express similar idiotopes (17-20). Alternatively, the F4 idiotype may be encoded with the VDJ junction and represent a particular $\mathrm{D}$ region gene sequence. We do not favor this hypothesis as the $\mathrm{D}$ region of the $\mathrm{H} 2 \mathrm{~F}$ antibody reported in this study differs substantially from that of the 2A4 antibody (8).

The IgG antibodies reported here bind dsDNA as well as the pentameric IgM antibodies despite the fact that IgM antibodies have higher avidity for antigen than their IgG counterparts. Therefore, the IgG antibodies must have higher actual affinity for dsDNA. This result was anticipated because in our studies of myeloma proteins we found DNA binding to be highly associated with IgG isotype in the 3 I idiotype system (1). The higher affinity of IgG antibodies found in this study may imply that DNA is a selecting antigen in the anti-DNA response and that affinity maturation occurs for anti-DNA antibodies. Confirmation of this interpretation will be possible once additional lines are available from each patient and the expressed variable region gene sequences and germ line gene sequences are known.

We were somewhat surprised to find that the IgM antibodies produced by the cell lines generated for this study bound dsDNA. The relative avidity of the IgM antibodies reported here for dsDNA is greater than that previously reported for germ line gene-encoded monoclonal IgM anti-DNA antibodies from SLE patients and normal individuals which have been shown by others to bind single-stranded DNA (ssDNA) but have little or no ability to bind dsDNA $(10,12,13,16)$. Binding to ssDNA is generally believed to be a property of nonpathogenic antibodies. Previous studies on myeloma proteins had suggested that 3I-reactive IgM antibodies infrequently bind DNA. That IgM producing 3I-reactive lines derived from SLE patients bind DNA is, however, consistent with the observation that IgM anti-DNA antibodies are not uncommonly present in the serum of SLE patients (22). There are several possible interpretations for this observation. The SLE-derived 3I-reactive IgM antibodies may preferentially use a subset of antibody genes that in their germ line configuration encode 3I-reactive dsDNA binding antibodies. It is also possible that SLE patients possess polymorphisms of immunoglobulin genes that lead to anti-DNA reactivity of germ line-encoded antibody molecules. Alternatively, IgM antibodies from SLE patients may be more likely to be mutated than those produced by malignant B cells; hypermutation may be a feature of SLE. Somatic mutation may occur earlier in B cell ontogeny or at higher frequency. Finally, EBV transformation may be selective for those $B$ cells that are activated and thus are more likely to have acquired mutations so that sampling an EBV-transformed B cell repertoire will yield different data than sampling a malignant B cell repertoire. The monoclonal proteins that express an autoantibody-associated idiotype but were derived from patients with monoclonal gammopathies may not faithfully mirror the idiotypically-related antibodies in autoimmune disease and reinforces the importance of technologies for directly studying the autoantibodies produced by nonmalignant B cells.

\section{Acknowledgments}

We would like to express our appreciation to Dr. B. Birshtein for critical review of the manuscript. We thank Ms. Rosalia Cawley and Ms. Millie Borgas for preparing the manuscript.
This work was supported by National Institutes of Health grant No. AR32371 and National Cancer Institute grant 13330. B. Diamond is a recipient of an Irma T. Hirschel award. Audrey Manheimer-Lory is a recipient of an Arthritis Foundation Fellowship.

\section{References}

1. Davidson, A., J. L. Preud'homme, A. Solomon, M.-d. Chang, S. Beede, and B. Diamond. 1987. Idiotypic analysis of myeloma proteins: anti-DNA activity of monoclonal immunoglobulins bearing an SLE idiotype is more common in IgG than IgM antibodies. J. Immunol. 138:1515-1518.

2. Halpern, R. A Davidson, A. Lazo, G. Solomon, R. Lahita, and B. Diamond. 1985. Familial systemic lupus erythematosus presence of a cross-reactive idiotype in healthy family members. J. Clin. Invest. 76:731-736.

3. Davidson, A., A. Smith, J. Katz, J. L. Preud'homme, A. Solomon, and B. Diamond. 1989. A cross-reactive idiotype on anti-DNA antibodies defines a heavy chain determinant present almost exclusively on IgG antibodies. J. Immunol. 143:174-180.

4. Ralph, P., J. Prichard, and M. Cohn. 1975. Reticulum cell sarcoma: an effector cell in antibody dependent cell mediated immunity. J. Immunol. 114:898-905.

5. Schwarzbaum, S., and B. Diamond. 1983. The J774.2 cell line presents antigen in an I region restricted manner. J. Immunol. 131:674-677.

6. Steffen, D., S. Bird, W. P. Rowe, and R. A. Weinberg. 1979. Identification of DNA fragments carrying ecotropic provirses of AKR mice. Proc. Natl. Acad. Sci. USA. 76:4554-4558.

7. Maniatis, T., E. F. Fritsch, and J. Sambrook. 1982. Molecular Cloning: A Laboratory Manual. Cold Spring Harbor Laboratory, Cold Spring Harbor, NY. 196 pp.

8. Davidson, A., A. Manheimer-Lory, C. Aranow, R., Peterson, N. Hannigan, and B. Diamond. 1990. Molecular characterization of a somatically muated antiDNA antibody bearing two SLE related idiotypes. J. Clin. Invest. 85:1401-1409.

9. Carson, D. A., and D. Friemark. 1986. Human lymphocyte hybridomas and monoclonal antibodies. Adv. Immunol. 38:275-311.

10. Cairns, E., J. Block, and D. A. Bell. 1984. Anti-DNA autoantibody producing hybridomas of normal human lymphoid cell origin. J. Clin. Invest. 74:880-887.

11. Casali, P., G. Inghirami, M. Nakamura, T. Davies, and A. L. Notkins. 1986. Human monoclonals from antigen-specific selection of $B$ lymphocytes and transformation by EBV. Science (Wash. DC). 234:476-479.

12. Hoch, S., P. H. Schur, and J. Schwaber. 1983. Frequency of anti-DNA producing cells from normals and patients with systemic lupus erythematosus. Clin. Immunol. Immunopathol. 27:28-37.

13. Shoenfeld, Y., J. Rauch, H. Massicotte, S. K. Datta, J. Andre-Schwartz, B. Stollar, and R. S. Schwartz. 1983. Polyspecificity of monoclonal lupus autoantibodies produced by human hybridomas. N. Engl. J. Med. 308:414-420.

14. Rauch, J., H. Massicotte, and H. Tannenbaum. 1985. Hybridoma antiDNA autoantibodies derived from rheumatoid arthritis and systemic lupus erythematosus patients. J. Immunol. 134:180-186.

15. Nakamura, M., S. Burastero, Y. Ueki, J. Larrick, A. L. Notkins, and P. Casali. 1988. Probing the normal and autoimmune B cell repertoire with EpsteinBarr virus. Frequency of B cells producing monoreactive high affinity autoantibodies in patients with Hashimoto's disease and systemic lupus erythematosus. $J$. Immunol. 141:4165-4172.

16. Chen, P. P., F. Goni, S. Fong, F. Jirik, J. H. Vaughan, B. Frangione, and D. Carson. 1985. The majority of human monoclonal IgM rheumatoid factors express a primary structure dependent cross-reactive idiotype. J. Immunol. 134:3281-3285.

17. Meek, K., D. Jeske, M. Slaovi, O. Leo, J. Urbain, and J. D. Capra. 1984. Complete amino acid sequence of heavy chain variable regions derived from two monoclonal anti-p-azophenylarsonate antibodies of $B A L B / c$ mice expressing the major cross-reactive idiotype of the A/J strain. J. Exp. Med. 160:1070-1086.

18. Zaghonani, H., F. A. Bonilla, K. Meek, and C. Bona. 1989. Molecular basis for expression of the A48 regulatory idiotope on antibodies encoded by immunoglobulin variable-region genes from various families. Proc. Natl. Acad. Sci. USA. 86:2341-2345.

19. Treppichio, W., and K. J. Barrett. 1987. Eleven MRL-1 pr/1 pr anti-DNA autoantibodies are encoded by genes from four $V_{H}$ gene families: a potentially biased usage of $V_{H}$ genes. $J$. Immunol. 138:2323-2331.

20. Capra, J. D., and T. J. Kindt. 1975. Antibody diversity: can more than one gene encode each variable region? Immunogenetics. 1:417-427.

21. Logtenberg, T., F. M. Young, J. H. Van Es, F. H. J. Gmelig-Meyling, and F. W. Alt. 1989. Autoantibodies encoded by the most $\mathrm{J}_{\mathrm{H}}$-proximal human immunoglobulin variable region gene. J. Exp. Med. 170:1347-1356.

22. Isenberg, D. A., C. Dudeney, W. Williams, I. Addison, S. Charles, J. Clarke, and A. Todd-Pokropek. 1987. Measurement of anti-DNA antibodies: a reappraisal using five different methods. Ann. Rheum. Dis. 46:448-456. 